PRIFYSGOL

glyndŵn

Glyndŵr University

Glyndŵr University Research Online

$1-1-2008$

\title{
The Chester Companies in the Seventeenth Century
}

Peter Bolton

Glyndwr University, p.bolton@glyndwr.ac.uk

Follow this and additional works at: http://epubs.glyndwr.ac.uk/hist

Part of the Cultural History Commons, and the Social History Commons

This article was published in the Transactions of the Historic Society of Lancashire and Cheshire, vol. 156 in 2008 and is available here by kind permission of the Historic Society of Lancashire and Cheshire. Their website can be found at http://www.hslc.org.uk/

\section{Recommended Citation}

Bolton, P. (2008) 'The Chester Companies in the Seventeenth Century'.Transactions of the Historic Society of Lancashire and Cheshire, 156

This Article is brought to you for free and open access by the Humanities at Glyndŵr University Research Online. It has been accepted for inclusion in History by an authorized administrator of Glyndŵr University Research Online. For more information, please contact d.jepson@glyndwr.ac.uk. 


\section{The Chester Companies in the Seventeenth Century}

Studies of Chester in the seventeenth century are not uncommon, with the civil war receiving particular attention. However, no modern study exists which considers the impact of that conflict on the companies of Chester and the guilds they comprised. This is understandable as civil war is usually no friend to the continuation of trade, especially in a city like Chester which endured the privations of a siege, and neither does it lend itself to accurate record keeping. Despite the silence of many company books and accounts there are, however, fresh and sometimes surprising conclusions to be drawn from the information that does survive. These conclusions are necessarily reliant upon an appreciation of company structure and organisation, without which the true extent of the conflict on Chester's trading community cannot be fully understood. Therefore, the purpose of this study is twofold: to provide a detailed history of the companies in the seventeenth century, and to consider the impact of the civil war on their trading capabilities.

Frank Simpson's various articles on the guilds or companies of Chester constitute the only major study of these organisations whose existence was so crucial to the prosperity of the city. Despite the excellence of these works, little attempt was made to compare the procedure or practice of these bodies as a whole and, in addition, Simpson did not deal with a particular period or theme, contenting himself with a progressive trawl through the various company books. These observations are meant in no way as a criticism of a work which retains a relevance even after the passing of almost a century. However, it does seem high time for a re-appraisal of the Chester companies and guilds, placing their structure, organisation and operations in the context of one of the most tumultuous periods of English history. 


\section{The Chester Companies in the Seventeenth Century}

A study such as this is necessarily reliant upon the original company books. These were completed by company stewards and include rules, oaths, fines, membership numbers, apprenticeship numbers, incomings and outgoings. Although a valuable source, some of these books are problematic. For example, the books of the Tanners and the Weavers do not commence until 1661 and 1697 respectively, whilst the book of the Drawers of the Dee covers the appropriate range but is water damaged and illegible. For these reasons, the primary sources used here are confined mainly, but not exclusively, to the company books of the Barber Surgeons, the Joiners, Turners and Carvers, the Smiths, Cutlers and Plumbers, the Bricklayers and the Skinners and the Feltmakers. Other useful primary sources, like order books and assembly orders, are also used where appropriate. Similarly, Frank Simpson's previously mentioned works, completed for this journal between 1911 and 1918, cannot be overlooked and receives frequent attention in this updated study. ${ }^{1}$ 


\section{The Chester Companies in the Seventeenth Century}

By the start of the seventeenth century Chester's trading organisations had long since divested themselves of that early modern regulatory body, the Guild Merchant, which had, since 1201, exercised control over trading affairs in the city. ${ }^{2}$ This control included the obtaining and enforcement of various royal grants. One such grant, in 1208, restricted trade in the city to the '...men of Chester and their heirs...', formally excluding non-residents and women from mercantile activities and establishing a system of hereditary trading rights. ${ }^{3}$ The much coveted status of 'freeman', bestowed by the Guild Merchant and a necessary qualification to carry out legal trade in the city, was, therefore, restricted to this Chester based fraternity. These restrictions continued well into the fourteenth century but, in a period pockmarked by plague and low life expectancy, they helped create a dearth of suitable candidates, which necessitated a widening of the franchise. Therefore, in 1392, apprenticeships were established which, when completed, allowed outsiders to join their respective company upon payment of a fee to the Guild Merchant for inclusion in the Freemen Rolls. ${ }^{4}$

By this time, the Guild Merchant had become something of an anachronism. Artisans were seemingly no longer content to submit themselves to the umbrella control of this ruling body, seeking instead to establish individual guilds for the better organisation and regulation of their own particular craft. The Tanners formed the first of these guilds in 1361 and others soon followed. One feature of this drive for independence was the petitioning of the Crown for Royal charters of incorporation. Such charters not only conferred trading monopolies, usually in return for payment to the crown, but also provided the guilds with a corporate identity, thereby allowing tradesmen the right to judicial appeal in trading disputes. The first successful charter was awarded in 1370 to the guild of Cordwainers, workers in Spanish 'cordwain' leather, who, in return, promised to pay '...8s $6 \mathrm{~d}$ to the Black Prince' for a monopoly on tanning leather. ${ }^{5}$ 


\section{The Chester Companies in the Seventeenth Century}

The reason for the breakaway of tradesmen from Guild Merchant control is unclear. Simpson takes the view that growing Guild Merchant exclusivity was to blame while Frank Hibbert, writing a little later, highlights factors more practical and political in nature. Understandably, both opinions suffer from a dearth of evidence, although a lack of trade protection during a sustained period of trade growth and diversification seems most likely. ${ }^{6}$ Whatever the reasons for this split, there can be little doubt that, by the beginning of the sixteenth century, artisan independence from Guild Merchant control was absolute. Furthermore, the independent guilds had, by this time, amalgamated with other guilds to form the various companies of Chester, with the mayor's book of 1475-6 listing nineteen such corporate bodies. This amalgamation was usually a practical way of combining crafts that shared similarities in the manufacturing process. The Smiths and Cutlers Company are the best example of this combination as they, in addition to the Smiths and Cutlers themselves, also list the Pewterers, Founders, Cardmakers, Girdlers, Headmakers, Spurriers, and Wiredressers among their numbers in their articles of $1490 .^{7}$

Helping to cement the position of these trading entities at the centre of city life was increased trade in general. This was especially true after 1506, when the 'Great Charter' of that year granted Chester independence from county and royal officialdom, investing it with the status of 'The County and City of Chester' ruled, like other important regional centres, by a locally elected Corporation or Assembly. It was a convenient transit point to and from Ireland and, throughout the sixteenth century, trade benefited from the influx of troops, officials and colonists sent there to impose English rule. Chester's role as the main trading centre of the north-west was reflected in increased company numbers, with 25 companies, comprising approximately 60 individual guilds, listed in the Mystery Play schedule of $1575 .^{8}$ 


\section{The Chester Companies in the Seventeenth Century}

The composition and organisation of Chester's companies, regulated by largely generic and reasonably inflexible rules and regulations, points towards a high level of trading coherence and maturity by the seventeenth century. Each company comprised one or two Aldermen, a couple of stewards and a common brotherhood whose numbers throughout most of the period ranged from approximately 20 to $60 .{ }^{9}$ All took oaths which reveal what was expected of them. The Aldermen acted as company Chairmen, bringing meetings to order and determining meeting schedules. To this end, the Oath of the Alderman included a promise to see that order was kept at company engagements and to allow new members to join only with the consent of the brotherhood. Elections were held every year but existing Aldermen were often re-elected, with some enjoying a position almost akin to a job for life. Robert Thorneley, for example, remained Alderman

of the Barber Surgeons for 23 successive years, until his death in $1651{ }^{10}$ Stewards, on the other hand, were usually changed every one or two years. Fiscal considerations were the main reason for this frequent changeover, as the stewards' most important task was that of book-keeping and, should company accounts fall short, they would be expected to make up the difference. An example of this fairly weighty burden of responsibility can be glimpsed in 1650. In this year the steward for the Merchant Drapers and Hosiers Company records his own payment of $2 \mathrm{~s}$ '...which I promised if I gott not John Davies quartring whoe is Dead...' indicating the failure of the steward to obtain the said fee when this particular member was alive. ${ }^{11}$ In accordance with this responsibility the Oath of the Steward required them to '...yielde up and give a true and just accompte...' of monies spent and received, or else suffer the consequences. 


\section{The Chester Companies in the Seventeenth Century}

Finally, the Oath of Every Brother applied to all remaining company members and included a promise to '...conceale, keep secret and not disclose such counsel... spoken of by the company...'. These oaths, which also stressed obedience and unity, were written into the Skinners and Feltmakers order book in 1615, although their largely generic pattern is replicated in most company books by our period. ${ }^{12}$

Some companies also included journeymen and women among their numbers. The former were men who had served their apprenticeship but were yet to pay the requisite joining fee which would confer full membership status. In 1646, the company book of the Joiners, Turners and Carvers lists 20 paid up members and eight journeymen; a figure which perhaps reflects the desire of some journeymen to remain as such and thereby avoid this often debilitating payment. ${ }^{13}$ The existence of women as company members should not be seen as a corporate desire for equality as they were neither allowed to vote in company meetings nor receive formal training. Indeed, women were only allowed to enter the ranks of a company on the death of their husband, who must himself have been a company member, and only with the express intention of carrying on his trade. The Barber Surgeons Company membership list of 1642 is suggestive of this central requirement. Here, 26 males are listed along with four females, the latter referred to as 'Widdows'. 14 Although these restrictions disqualified wives of existing members from close involvement in company affairs, there is evidence to suggest these women were required to conform to the same levels of conduct expected of their menfolk. An example of this occurs in 1656 when the wife of William Seale is reprimanded for ‘...calling William Selbeys wife a whore \& a silly queene, several times...'. But this admonition, handed down by the Butchers Company of which Mr. Seale was an active member, should not be read simply as interference into the daily lives of those with only indirect company ties. Instead, such examples can also be viewed as evidence of the way in which companies afforded a level of protection, on this occasion to the reputation of Mrs. Selbey, to those who occupied a largely anonymous legal position in society at large. ${ }^{15}$ 


\section{The Chester Companies in the Seventeenth Century}

Mrs. Seale's upbraiding took place at one of frequent company meetings. Such meetings were not only vital in ensuring the smooth running of a company but were crucial for the continued existence of all these trading bodies. This was particularly true in the seventeenth century when trade diversification had reached its peak, leading to the growth of small, specialised guilds whose harmonious existence within a corporate body relied upon the accepted codes of practice formalised in such gatherings. This increased importance is borne out by the growth of permanent meeting places in this period, with the most popular meeting place being the Phoenix Tower situated on the north east corner of the city walls. ${ }^{16}$ The Barber Surgeons and the Painters, Glaziers, Embroiderers and Stationers Company sought to convert the tower into a permanent meeting place via a joint tenancy agreement of 1613. The company book of the Barber Surgeons reveals that each company contained 16 members at this date who together contributed approximately $£ 48$ for '....repayringe and buildinge the tower [and] a parte of the walls adjoyninge...'. As part of the agreement, the Butchers Company and that of the Fletchers and Coopers, were allowed to retain their right to meet in the 'Lower house' of the tower, each contributing $£ 1$ for the upkeep. ${ }^{17}$ This source also reveals that, by 1657 , the Barber Surgeons, as proprietors, were receiving rent from the Joiners, Turners and Carvers, the Weavers, the Clothmakers and the Bakers Company, all of whom used the Phoenix Tower as a permanent meeting place. ${ }^{18}$

Volume II of the company book of the Smiths, Cutlers and Plumbers shows this company was to have four formal meetings a year. These were to follow certain feast days and the venue was the Commonhall, near the Cathedral. For most of the seventeenth century this building was leased from the Assembly, although the company was responsible for its upkeep paying $7 \mathrm{~s} 3 \mathrm{~d}$ for '...repayringe the Meetinge house...' in 1636. ${ }^{19}$ By the end of the century they owned the Commonhall outright and were themselves acting as landlords. By this time, the Bricklayers, the Skinners and Feltmakers and the Merchant Drapers and Hosiers Company were each paying an annual rent of $5 s^{20}$ 


\section{The Chester Companies in the Seventeenth Century}

Another important meeting place was the Glovers Hall on Duke Street. The Glovers owned this building and, like other proprietors, sublet it, receiving rents from the Beerbrewers, the Innkeepers, the Slaters and the Dyers. ${ }^{21}$

Quarterly meetings were common to all companies and attendance was compulsory. Stewards would be fined if they failed to warn members of a date change or emergency meeting. One example of this came in 1636, when the Smiths, Cutlers and Plumbers received $12 \mathrm{~d}$ from '...our 2 Stewards for leavinge 4...brethren unwarned of our Meetinge'. ${ }^{22}$ Unwarranted non-attendance also carried a fine and, in the case of the Feltmakers Company, in 1681, members would have to '...paie for every abscence the sum of $3 \mathrm{~s} 5 \mathrm{~d} . . .23$ These meetings were vital for company finances as all members, in addition to sundry fines, were expected to pay their 'quarterage' or membership fees. Using the Bricklayers Company as a common example this fee amounted, in 1683, to '...one shilling of lawfull money...' per person, every quarter, with a 2 s fine for non payment. $^{24}$

The busiest and most important of these quarterly meetings was election day. This was greeted with bell ringing in the city, with a standard charge for this service, approximately $3 \mathrm{~s} 4 \mathrm{~d}$ by mid-century, forming a common entry in most company accounts. ${ }^{25}$ Each company held their election day on the day of the Saint with which they were associated - for example Saint Dunstan for the Goldsmiths and Saint Martin for the Saddlers and Curriers. As well as illustrating the intrinsic link between the companies and religion, such association also performed a more practical function. The adoption of saintly images on company regalia provided an effective form of visual advertising in an age of general illiteracy. The day of the elections, as well as allowing new Aldermen and stewards to be elected or existing ones to be re-elected, was also the day of the annual count, where membership numbers were recorded. 


\section{The Chester Companies in the Seventeenth Century}

Like other meeting days, election day was important primarily for financial reasons. For company members it was the last opportunity to pay outstanding quarterage fees or fines before facing further punishment. Accordingly, the Smiths, Cutlers and Plumbers record a receipt of $8 \mathrm{~s}$ in 1636, 'Recd of 8 brethren for theire fines [for] Denyinge to pay their accounts the last Election Day.... ${ }^{26}$ More importantly, new members, having served their apprenticeship, would take their oath on this day and pay to join the company, with the fee involved dependent on a number of factors. Nepotism was one such factor. Apprentices with no family connections would pay more than those with relatives in the company - a condition of entry most companies made no attempt to hide. The rules of the Bricklayers Company, in 1681, declare that '...any brothers sonn...'

would pay 30 s whilst anyone else would pay $£ 3 .{ }^{27}$ In the Smiths, Cutlers and Plumbers receipts for 1637 three men, George Pickmere, Edward Ryder and David Griffith, paid £2 13s 3d each. Three others, William Lewis, John Morris and John Gough, who, unlike the former trio had no pre-existing company ties, paid $£ 46 \mathrm{~s} 8 \mathrm{~d} \mathrm{each.}{ }^{28}$ On the rare occasions that non-freemen, those not born in Chester or not having served an apprenticeship in the city, were given special Assembly dispensation to join a company, a much higher fee was involved. Consequently, Steven Owen, who joined the Smiths, Cutlers and Plumbers in 1642 , paid the considerable sum of $£ 1918$ s $6 \mathrm{~d}$ for the privilege. ${ }^{29}$

Rounding off election day, and surely helping to make it one of the most eagerly anticipated days in a company's calendar, was the annual dinner. This took place in inns, meeting houses or the homes of company Aldermen and offered much opportunity for overindulgence. The Smiths, Cutlers and Plumbers Company were perhaps the most extravagant diners. In 1641 they paid '...for our banquet...' the sum of $£ 110 \mathrm{~s} 6 \mathrm{~d}$ for, among other things, meat, strong beer, wine, vinegar and pepper. In 1649, they paid for '...Dinner at Alderman Malbons house upon our Election day' the grand sum of $£ 41 \mathrm{~s} 2 \mathrm{~d}$. The excesses this sum suggests perhaps explains the additional $4 \mathrm{~s}$ they paid for '...Washing the Linen...' afterwards. ${ }^{30}$ Others, like the Barber Surgeons and the Merchant Drapers and Hosiers, enjoyed a musical accompaniment to their celebrations, with both recording regular sums that were 'Payd to the Musike'. ${ }^{31}$ 


\section{The Chester Companies in the Seventeenth Century}

Despite the suggestion of fun and frivolity contained in the above examples members were, for the most part, expected to behave themselves at company meetings. The 1681 rules of the Skinners and Feltmakers Company included a $12 \mathrm{~d}$ fine for anyone who '...doe swear or curse in the meeting house...' and a $5 \mathrm{~s}$ fine for anyone who interrupted a brother who was '...telling of theire matters' ${ }^{32}$ John Davies, son of the late John Davies mentioned above, must have caused great offence in 1655, by his '...many approbrious speeches...' as he was fined 20s by the Merchant Drapers and Hosiers Company. This company, like many others, also taught members reverence for their elders and each other, fining brethren $3 \mathrm{~s} 4 \mathrm{~d}$, in 1640, if they '...doe call any brother Knave or such like evill words.... ${ }^{33}$ Like most, the Bricklayers Company included fines - 2s in 1681 - for any brother who left the meeting before it was concluded by the Alderman. William Seale incurred such a fine for leaving the Commonhall prematurely during a meeting of the Butchers Company in 1659. His wife, who we met earlier, seems to have been the reason for this desertion, although we can only guess the reasons for her entering the meeting hall and commanding her husband to leave, adding '...must thou be every doggs skavinger...' 34

Meetings also provided members with an occasion to show off their finery. The wearing of livery had long emphasised hierarchical structure and provided an indication of company wealth. By the seventeenth century, company uniforms were either green and black or green and scarlet. Their main constituent was a fur trimmed cloak or gown, with the quality of fur often reflecting status. In this period the wearing of such garments

does not seem to have been confined to senior company members. In 1681 the Bricklayers Company fined any member who '...come to any of our meetings...not in a Gowne...' the sum of $2 \mathrm{~s}$. 


\section{The Chester Companies in the Seventeenth Century}

A similar rule had been passed by the Merchant Drapers and Hosiers Company in 1637. The Barber Surgeons dress codes, this time from 1607, were more specific. Every brother that had been with the company for at least two years was required to wear a gown. This requirement was particularly expected of married men who, in addition to the promotion of solidarity and company identity, were required to display an example of moral rectitude to their unmarried colleagues. ${ }^{35}$ When a meeting ended, status and organisation were once more to the fore, as illustrated in the rules of the Smiths, Cutlers and Plumbers Company, agreed upon in 1607. Here, brothers were not allowed to leave haphazardly at the end of every meeting. Instead, they were compelled to depart in '...decent order...accordinge to theire Callings and Seignioraties...', what the Barber Surgeons, in their rules of the same date, refer to as their '...office and place... ${ }^{, 36}$

Despite the formality and occasional exuberance exhibited in these meetings, we should not lose sight of the fact that the central importance of these frequent gatherings lay in the collection of debts, rents and fees. These constituted the very lifeblood upon which the existence of the Chester companies depended. This existence came under threat during the English civil war, a conflict which directly affected Chester from January 1643 to February 1646. During much of this period, the city lay under siege and John Morrill has demonstrated that Cheshire suffered a complete governmental and administrative breakdown, similar to that of countless other counties. ${ }^{37}$ Dislocation of trade inevitably followed as supply lines were disrupted. An indication of this disruption on the trading community is provided by the Freemen Rolls, which record no new entries between 1645 and 1646, when the siege was at its most critical stage. ${ }^{38}$ In addition, the consequences of war continued to exert a largely negative influence on the companies for some considerable time after the danger to Chester had abated. Analysis of the true extent of this threat is made difficult by a distinct lack of primary source material. Most company books fall silent during the civil war years, recording none of the incomings or outgoings that might reflect the hardship suffered. This dearth of information is perhaps in itself the best indicator of what Parry refers to as the 'obvious catastrophe' that befell the companies during the wartime period. ${ }^{39}$ 


\section{The Chester Companies in the Seventeenth Century}

However, some sources do survive whose content, as well as their very existence, suggest that a total breakdown of company structure and organisation was avoided by some. Many companies still continued with their annual election days throughout the conflict and, although there are few recorded instances of annual dinners taking place the ostentatious Smiths, Cutlers and Plumbers being a notable exception - annual head counts are recorded in many company books. ${ }^{40}$ The analysis carried out in appendix one illustrates the extent to which the membership of some companies was affected by the civil war. Although not all years are catered for, these figures do suggest a general stability of membership during the hostilities. Between them, the Joiners, Turners and Carvers and the Barber Surgeons Company record just three fewer members in 1646 than they do in 1642. Furthermore, the Mercers Company record a growth in membership during the same period. The Merchant Drapers and Hosiers Company show some fluctuation in 1644 but, within a few years, their membership is restored to the level it had been in 1643 .

Despite retaining some vestige of control, however, the effective running of many companies must have been severely hampered by the loss of their most important means of organisation - the Meeting House. The Phoenix Tower, home to so many gatherings, was commandeered in 1643 '.. for the planting of several ordinance for the defence of the city...'. It was largely destroyed in 1645-46 during the siege on the city and Randle Holme, steward of the Painters, Glaziers, Embroiderers and Stationers Company, was charged with its restoration. ${ }^{41}$ This work continued long after the war ended and, as late as 1658, Holme records costs incurred in the '...raising of the tower two feet higher than...before'. The total sum involved in this rebuilding was $£ 2418$ s, split evenly between the above company and the Barber Surgeons. ${ }^{42}$ 


\section{The Chester Companies in the Seventeenth Century}

In March 1645, Randle Holme also recorded the destruction of '....all ye Glover's [ware]houses under the walls...'. This tactical manoeuvre by the city authorities to restrict the shelter afforded to their Parliamentarian protagonists, resulted in the Glovers Company not only losing their meeting place but also their workshops. Although some, like the Barber Surgeons, continued to meet at the houses of their Aldermen, the Wet and Dry Glovers record no meetings or election days between 1645 and $1653 .^{43}$ By this later date company membership was still relatively healthy, with 38 names listed. However, this compares unfavorably with the 51 members recorded before the hostilities began. The sense that this company, one of the oldest in Chester, never fully recovered from the civil war, is provided by their count of 1666, where just 26 members are returned. ${ }^{44}$

In addition, the companies of Chester also suffered from the inevitable human loss associated with war. The Innholders Company, in 1644, record a membership of 30. However, this figure includes nine names marked as 'absent'. Facilitating such absence was the Commission of Array, established in the city in 1643 to recruit all able-bodied men to the Royalist cause. This compulsory recruitment would obviously have had a debilitating effect on the Innholders Company, whose register of 1643 contains 19 members who satisfied the 16 to 60 age range required of by the Array. ${ }^{45}$ In addition, there were many Royalist soldiers described as ‘...Chester men, as Shoemakers, Cobblers, Taylors, Barbers and the like...', captured, with some being killed, in January $1645{ }^{46}$

Although ostensibly a Royalist city, Chester also lost men to the Parliamentarian cause. The Merchant Drapers and Hosiers Company, at a meeting in October 1644, were required to act upon the sum of 43 s owed to them by one Peter Sneade. This man had previously been a steward of the company but, like all those with Parliamentarian leanings, had been banished from Chester by the city authorities. In addition, the same company held an emergency meeting in November 1645 to elect a new Alderman in place of Robert Ince who, like Sneade, had been '... commanded and expulsed [from] the Cittie'. ${ }^{47}$ 


\section{The Chester Companies in the Seventeenth Century}

Many companies also suffered from non-payment of membership fees which, for most, constituted their only regular source of income. In this respect, the Barber Surgeons were lucky as their, albeit minor, surgical skills were an obvious boon during wartime. Even during the height of the siege on the City in 1645, this company records all fees as paid, even by the three members absent from the meeting of that year. ${ }^{48}$ However, others, like the Mercers Company, were far more typical. In 1644, almost half

of their 49 members failed to pay their fees and, by 1646, not one quaterage is recorded. ${ }^{49}$ The end of the siege came with the city's surrender in January 1646, a capitulation which also marked the end of Chester's direct involvement in the civil war. However, the indirect effect of this conflict was perhaps more damaging for the companies of Chester than the human and material loss sustained during hostilities. One indirect casualty of the war was the breakdown of apprenticeship indentures controlling recruitment into the companies. These indentures were the agreements made between the apprentice and the master which dictated length of apprenticeship and codes of conduct. Apprenticeship indentures had to be enrolled with the relevant company in a timely manner. In the case of the Skinners and Feltmakers Company this enrollment, if not carried out within two weeks of receiving the apprentice, meant a $12 \mathrm{~d}$ fine for the member involved. Before the war, such measures ensured apprentice numbers were controlled and the apprentice joining fee, $6 \mathrm{~d}$ for the above company, was received. ${ }^{50}$

There were obviously unlicensed apprentices in the city during wartime, hence the Assembly edict, of December 1646, which sought their regulation. ${ }^{51}$ However, the confusion and disruption of war, and its aftermath, meant that, between 1643 and 1649, just one apprentice, a mercer, was enrolled and entered onto the apprenticeship lists. ${ }^{52}$ Adding to these problems was the Parliament Act, passed in December 1647, which granted freemen status to all those apprentices who had served the Roundhead cause, irrespective of the length of apprenticeship still remaining. ${ }^{53}$ This act undermined Assembly attempts to bring apprenticeship indentures back into line. It also bypassed company rules, with all companies demanding an apprenticeship of at least seven years a term usually strictly enforced. 


\section{The Chester Companies in the Seventeenth Century}

In 1657, for example, Michael Hunt was expelled from the Smiths, Cutlers and Plumbers Company for freeing an apprentice who had served two of his seven years in another city. ${ }^{54}$ Such constraints, as well as protecting local interests, also ensured that apprentices, when eligible for freedom, were suitably qualified.

In addition, the granting of free status was usually conditional, primarily to protect company trade and identity. This can be seen in the case of Edmund Heywood. He was apprenticed to the Weavers Company and, in 1607, was only granted his freedom on the promise that he would only practise the trade of buying and selling linen, and only for so long as he lived in Chester. ${ }^{55}$ It is debatable how damaging the Parliament Act, and a further one passed in 1654, would have been to the companies of Chester which was, after all, a Royalist stronghold. ${ }^{56}$ However, as Alison Johnson demonstrates, Royalist support in Chester was 'narrow-based and self-interested' and confined mainly to the Aldermanic Bench. Claims to the contrary by Frank Simpson rather reflect the Royalist leanings self-evident in his work from time to time and, as the previous examples of Sneade and Ince suggest, are not wholly accurate. ${ }^{57}$

The most serious post-war threat to the companies of Chester arrived in the form of plague. This swept through the city between June 1647 and April 1648 and was a direct result of the wartime collapse of sanitation and close billeting of soldiers and citizens alike. In this period, described by the Barber Surgeons Steward as the '...tyme of the Lords Dreadfull visitation...', Chester lost approximately one third of its population. ${ }^{58}$ Not surprisingly, the companies of Chester were badly affected. The Joiners, Turners and Carvers Company, who record 20 members after the hostilities ended, state that seven members were missing from the meeting of 1647. By 1648, although the election day was fully attended, the actual membership stood at just eight. The Barber Surgeons Company, in the same period, lost four of their 24 members and the Merchant Drapers and Hosiers Company, despite recording 21 members in 1646, state that four died during the year. By the time of their election day, in September 1647, the Drapers record an absence figure of $80 \%$. The company steward removes the need for analysis or conjecture, explaining simply that '...the plague was in Chester..." 59 


\section{The Chester Companies in the Seventeenth Century}

Illegal trading from all quarters was an inevitable outcome of the disruption caused by civil war, plague and the resultant breakdown of company regulations. Common grievances included those like the Saddlers and Curriers Company who complained, along with the Spurriers guild in January 1647, that Stephen Owen of the Cutlers guild had sold spurs since the war began. This, they argued, encouraged other cutlers to follow suit and was in direct contravention of their trading monopoly. ${ }^{60}$ Furthermore, the Merchant Taylors Company, in 1648, petitioned against widows of their own company who had hired outsiders to cut cloth, thereby depriving their members of trade. Additionally, the Innholders Company complained that many outsiders kept inns and victualling houses in the city during the troubles and, as late as 1654, the Joiners, Turners and Carvers were complaining that private citizens were buying timber to re-sell during the frantic rebuilding phase. ${ }^{61}$

Despite these disruptions, many companies obviously regained a level of stability via the rebuilding programme, which continued throughout the 1650s, and the alleviation of the trading blockade following the end of the siege. The individual guilds of Carpenters, Plasterers, Slaters, Masons and Pavers, and the Company of Bricklayers, obviously profited from the building works too much, hence the Assembly judgment, in December 1653, stating they had '...exacted more wages than previous from the inhabitants... ${ }^{62}$ A return to normality can also be glimpsed in the records of the Skinners and Feltmakers Company who, by 1654, were claiming that 500 people relied on their trade whilst others, like the Mercers Company, recorded a membership which, by 1649, was higher than its pre-war figure. ${ }^{63}$ Post-war stability, despite the lack of sufficiently maintained records, is also indicated by the activities of the Smiths, Cutlers and Plumbers Company who, by 1700, enjoyed sufficient financial health to finally buy their meeting house, the Commonhall, from the Assembly. ${ }^{64}$ 


\section{The Chester Companies in the Seventeenth Century}

Although Randle Holme would later claim the civil war, and its aftermath, was a time in which '...God of heaven humbled this famous cittie', the evidence suggests such humility was short-lived by the Chester companies. ${ }^{65}$ Indeed, many benefited from the artificially high demand caused by years of enforced austerity and the necessary rebuilding of the city which continued throughout the 1650s. ${ }^{66}$ Activities associated with trade protection account for a considerable proportion of all company records and, by this time, these activities were carrying on efficiently, providing further evidence of the relative ease with which many companies were able to return to normality so soon after the civil war.

Non-freemen, or 'foreigners' as they appear in most sources, were only allowed to trade in the city during the two Great Fairs held there every year. These took place in July and October and lasted for a total of 30 days. ${ }^{67}$ Fines and punishments for those involved in illegal trading, in addition to the monies paid to enforce trading monopolies, form the backbone of most company accounts. Thomas Knee, for example, was paid 1s by the Merchant Drapers and Hosiers Company in 1653 '...for Calling three women before Mr Maior that sold flannel'. Similarly, in 1637, the Smiths, Cutlers and Plumbers Company spent $4 \mathrm{~d}$ '...taking up a stranger w[hich] sould Iron-ware' and double that amount, perhaps not surprisingly given the ostentatious nature of this company, on wine for '...takeinge upp a stranger shoeinge horses...' shortly after. ${ }^{68}$ Such cases were common and could be complicated as well as costly. The Barber Surgeons' steward details a meeting held in 1693 '...Concerning ye Indictments aganst foraigners'. The next morning is spent in bringing witnesses together followed by a payment of $7 \mathrm{~s} 6 \mathrm{~d}$ to a legal clerk for drawing up the indictments. Finally, the King's Attorney is paid 13s $4 \mathrm{~d}$ for '...signing the said indictments', an overall cost suggestive of the seriousness of the threat posed by interlopers. ${ }^{69}$ 


\section{The Chester Companies in the Seventeenth Century}

Trade protection measures did not just apply to outsiders entering the city, as rival company members were also liable for prosecution. Apprentices, as already seen in the case of Edmund Heywood, had to swear to follow only that trade in which they had received their apprenticeship. Such promises were frequently broken. Heywood himself, along with three others, was threatened with disenfranchisement by the Assembly in July 1613. This followed an accusation against Heywood by the Mercers Company, who complained he was selling, among other things, 'silkes of all coulours' despite never having served an apprenticeship with the Mercers who carried the exclusive rights to such trade. ${ }^{70}$

Interestingly, trade protection measures, so often associated with profit and insularity, were also enacted by companies to prevent their own members monopolising trade to the detriment of their brothers. To this end, the rule preventing any brother from owning more than one shop can be found in all company books. ${ }^{71}$ Thomas Persyval, of the Saddlers and Curriers Company, was one of many who fell foul of this law when, in 1603, he was ordered by the Assembly to '...exercise his occupacon... in one shop only' ${ }^{72}$ Similarly, in 1626, the Shoemakers Company expelled their own steward, William Allen, for having two shops, one of which lay in Wrexham, outside the city walls but obviously not outside company jurisdiction. ${ }^{73}$ Other rules seeking to prevent internal monopolisation were in effect elsewhere. The Barber Surgeons Company, which incorporated the Tallowchandlers guild, passed two laws in 1607 and 1613 which prevented individuals from buying more than $£ 10$ worth of tallow. This came about after one unnamed brother monopolised candle production through the purchase of cheap tallow from a nearby supplier, thus forcing the '...weaker (i.e.: poorer) sort of ...brothers...' to buy from afar and at more expense. The Tanners Company, in another example of fair play, ruled in c.1630 that brothers could use only one supplier per year and could buy only one skin per day. ${ }^{74}$ 


\section{The Chester Companies in the Seventeenth Century}

This period also saw a growth in rulings designed to maintain quality and integrity influenced, no doubt, by the sort of steady expansion and diversification as much a threat to traditional values in the seventeenth century as they are to such values today. Promotion of these values encouraged a form of brand loyalty which possibly goes some way to explaining the rapidity with which some companies returned to normality following the civil war. The laws governing apprenticeships, dealt with in more detail above, were the most important for inculcating best practice as they consistently bound acolytes for a minimum of seven years. Additional quality control took the form of visitations made to members by senior company officials. The Barber Surgeons Company record many fines for inadequate workmanship, such as the one in 1651 incurred by a brother for '...his wanting [of] waight in his candles'. The steward's expenditure, this time in 1689, for '...goeing about to weigh Candles' suggests such practice was continuous and thorough. ${ }^{75}$ Similarly, in the previously mentioned ruling against William Allen, the Shoemakers Company justified their action by claiming Allen could sell 'insufficient wares' as there were no officers in the Wrexham area to inspect his goods for quality. ${ }^{76}$

The above examples illustrate the desire of the companies to safeguard centuries old trading rights, whilst instilling and maintaining integrity and equality among their membership. However, the accrual of wealth through collective trade monopolisation brought with it certain communal expectations. The most important of these, in the

seventeenth century, was the Midsummer Show. ${ }^{77}$ Held on Midsummer's Day, this pagan carnival involved each company in a procession through the streets, enacting a play, or 'pageant' as they went. 


\section{The Chester Companies in the Seventeenth Century}

Such pageants would involve the hiring of performers and the use of sophisticated cardboard props, depicting mythical creatures like giants, unicorns and dragons. These displays were usually lavish. The Smiths, Cutlers and Plumbers Company record expenses in 1640 totalling some $£ 3$ for, among other things, 'Gundpower' (13s), 'bootes \& Gloves \& Ribbon' (11s) and, characteristically, 15s 3d for a banquet which followed the procession. In 1661 one company paid 10s 10d for the giant's whiskers alone. Similar costs are recorded by the Barber Surgeons Company, whose provision for a '...young stripling or boy to ride Isaac...', the company horse who led the procession, actually formed a part of their company rules. ${ }^{78}$

The importance of the Midsummer Show, the only major form of free public entertainment in seventeenth century Chester, was not just confined to its entertaining nature. Events like this, and the more exclusive horse races, allowed the various guilds and companies to show off the splendor of their company regalia, examples of which can be found in the appendices. ${ }^{79}$ These included cloaks, hats, sashes and 'tippets', the latter worn suspended from the back of the collar by company officials. Such ostentation provided a visible sign of company superiority and wealth. In addition, banners would accompany every social occasion. The differing sums involved in the procurement of these banners provide an indication of company wealth, as well as illustrating the respective company desire to be noticed. 


\section{The Chester Companies in the Seventeenth Century}

Accordingly, the Butchers Company paid the not inconsiderable sum of $£ 212 \mathrm{~s}$ $10 \mathrm{~d}$ in 1661 '...for ye company collours'. Three years later, the Barber Surgeons Company paid £4 '...for the new flag'. However, it is no surprise that the most ostentatious company, the Smiths, Cutlers and Plumbers, were also the most extravagant, paying approximately $£ 6$ for their new banner in $1664 .^{80}$ This company also used social occasions to show off its proudest possession, a silver badge awarded to them by Prince Arthur, brother of Henry VIII, in $1499 .{ }^{81}$ Other items were used as a display of guild identity. Members of the Cutlers Guild, for example, had their own banner, albeit much smaller than their company colours, and wore medallions which highlighted their individuality.

Although the real financial importance of the companies of Chester lay in the various customs and taxes their trade generated, social events, whether company orientated, like election days, or more communal, like the Midsummer Show, were also

important for the redistribution of wealth. ${ }^{82}$ The main beneficiaries were usually other tradesmen, especially the numerous innholders who profited greatly from company and incidental trade on such occasions. However, other, less fortunate types, like the '...poore woman under the meetinge house' who received $4 \mathrm{~d}$ or the 'prisoners' who received $1 \mathrm{~s}$, also benefited from company charity during these events. In addition to taxes and celebratory largesse, sums were regularly paid to the poor who lived in the city alms houses, with payments made to old or maimed soldiers also a recurring feature in company expenses. ${ }^{83}$

These acts of Christian charity were in line with the companies' maintenance of religious sanctity in general. Company members were regularly fined for contravening laws banning trade on days of religious significance. For example, the Barber Surgeons Company record a cost for '...takeing of the barbers before the Mayor for the keeping of the Sabbath' in 1656. Elsewhere, Richard Price, a member of the Butchers Company, received a fine in 1660 for '...Cuttinge a Calfe upon good Friday'. ${ }^{84}$ 


\section{The Chester Companies in the Seventeenth Century}

One company undertaking which combined religion with social responsibility was the attendance of company members at the funeral of a colleague, considered a 'deed of love and charity among Christian brethren'. ${ }^{85}$ Compulsory attendance was not just confined to the funeral of brothers, but also, in the case of the Skinners and Feltmakers Company, to their wives and children too. The social importance of the companies to all those connected with the trading network is perhaps best illustrated by the funeral obligations of the Barber Surgeons Company. In an act of almost trade unionist solidarity, this company, in its rulings governing compulsory attendance, stipulated that not only were the funerals of brothers and next of kin to be attended, but the funerals of the servants of any brother were also to be accorded the same honour. ${ }^{86}$ In addition, brothers were aided financially in life as well as death, with the Smiths, Cutlers and Plumbers Company, in just one example of many, contributing 10s to '...Urien in his sickness' in 1660. This gesture was obviously futile as the company records a similar sum, later in the same year, for the unfortunate brother's coffin. Despite this, it was probably some comfort to the soon to be departed that company rules regarding the dead would ensure a decent, or at least decently attended, funeral. ${ }^{87}$

The social, economic and religious responsibilities of the companies of Chester were, to a large extent, dictated by the city Assembly. However, the demands made by this ruling body do not appear to have been too taxing on the trading community of the city. This is perhaps not surprising given the makeup of the Assembly which comprised 24 company Aldermen and 40 common councillors drawn from the freeman ranks of this community. ${ }^{88}$ The highest civic position, that of Mayor, was also filled by a company Alderman and, in 1655, the Merchant Drapers and Hosiers Company celebrated with two sugar loaves when they visited '...our Master after hee was chose Maior'. ${ }^{9}$ The benign relationship between this Assembly and the companies of Chester can perhaps be best seen in the rulings of the former. On only two occasions in the seventeenth century did the Assembly rule against a company or guild. The rest of the time, these trading bodies were allowed to resolve differences internally, often with as little recourse to democracy as possible. $^{90}$ 


\section{The Chester Companies in the Seventeenth Century}

Although the seventeenth century marked the high point of company influence and control, it could be argued that it was also the century in which the seeds of decline were sown. Much of this decline was initiated by the acceptance of men into the various companies who practised a trade different from that which their company or guild sought to protect. To this end some companies, like the Bricklayers, in 1680, passed laws which forbade members from taking on apprentices who were married men. ${ }^{91}$ In many cases such men were not freemen of the city and their motivation for seeking an apprenticeship, often in middle-age, was purely to provide their sons with this hereditary status which would prove useful in later life irrespective of the trade they chose to follow. The Smiths, Cutlers and Plumbers Company recognised this threat to their identity when they passed a law in 1670 which prevented the taking on of apprentices who '...shall bee married or have infant children... . $^{92}$

The event which ensured the long-term survival of the companies of Chester also contributed to their decline after the seventeenth century. Owen Jones, described by Simpson as 'the greatest benefactor the City Gilds have ever had', was a member of the Butchers Company and a moderate landowner. In his will of 1658 he bequeathed the profits of his land '...to the poore of every company of the Citty of Chester...' in

perpetuity. Every year a different company, dependent on the order they took in the Midsummer Show, would receive the dividend. ${ }^{93}$

In 1743, the total income was just £16. By 1782, however, lead had been discovered on the land, in Minera, and the total dividend for that year, shared out among the 22 members of the Barber Surgeons Company, was $£ 10,260 .^{94}$ This had an adverse effect on some companies, like the Skinners and Feltmakers and the Merchant Taylors, who sought to restrict membership numbers and thus share the dividend among a smaller group. Since 1690 the Assembly had taken measures to combat the apparent decline of those admitted to the status of freemen as, from this date, all men with useful skills were accorded this status and allowed to practise their trade largely independent of company control. $^{95}$ 


\section{The Chester Companies in the Seventeenth Century}

This control was further eroded from the mid-eighteenth century and the onset of the Industrial Revolution. Although Groombridge claims this event had little effect on Chester's companies as the surrounding area lacked in any significant mineral wealth, the evolutionary nature of industrialisation - the move towards mass production significantly undermined the artisan classes of which the companies of Chester comprised. $^{96}$

Finally, in 1835, the Municipal Corporations Act divested Chester's ruling Assembly of its power. Through this act the companies lost their political influence and a ruling body sympathetic to their trading monopoly. However, by this time trade diversification and industrialisation had virtually destroyed the identity and protectorate role of the companies of Chester, with many existing as no more than social clubs. The Beerbrewers Company, for example, had just three members in 1835, while the Skinners and Feltmakers had just two. ${ }^{97}$

However, even the onset of industrialisation and governmental reform could not totally destroy the unity of this common brotherhood. Of the 25 companies which existed at the start of the seventeenth century, 23 still remain today, many of whom underwent a mid-eighteenth century revival when the proceeds of the Owen Jones bequest were organised to provide pensions and education for company members and their families. ${ }^{98}$ Certain traditions still persevere but social events, rather than trade protection, are more likely to form the basis for discussion in the frequent meetings that still take place. The institution of a permanent meeting house is still intact, but there is now just one, the Guildhall in Watergate Street. Membership requirements have changed little since the seventeenth century, with only those born in Chester or serving a trade eligible to join the city companies. In addition, the sense of fraternity still perseveres, with women having only been admitted since 1993 and only then as daughters of freemen. ${ }^{99}$ 


\section{The Chester Companies in the Seventeenth Century}

The social exclusivity practised by the surviving guilds and companies of Chester today, owes much to the traditions and conventions inherited from their seventeenth century predecessors. The latter exercised a trading hegemony, the influence of which extended to all spheres of city life, and the strength of this combined brotherhood, united by largely uniform laws decided and acted upon in regular meetings, could not be broken by frequent internal or inter-company disputes. The civil war, and its after-effects, were more damaging but even this event, which proved calamitous for the royal prerogative, did not prove disastrous for the companies of Chester, most of whom had resumed their former prominence by the time of the Restoration. 


\section{The Chester Companies in the Seventeenth Century}

\section{NOTES AND REFERENCES}

1. The primary sources mentioned in this study are available in the Cheshire Record Office and the works of Frank Simpson are available in Chester Library. Other miscellaneous sources are available at the Cheshire History and Heritage Centre.

2. Frank Simpson confers on this 'Gilda Mercatoria' the role of trade regulator while a more recent view claims this body was unlikely to have been associated with trade. For both views see F. Simpson, 'The City Gilds or Companies of Chester with special reference to that of the Barber Surgeons', Journal of the Chester Archaeological Society, new series, (hereafter J.C.A.S.), 18 (1911), p. 98 and H.E. Boulton, The Chester Mystery Plays (Chester, 1980), p. 4. It seems reasonable to suggest the original Guild Merchant administered trade even if its members had no direct trade involvement, a connection reinforced by the Chester Hand or Glove, an early wooden artifact bearing the inscription: 'Hugh Earl of Chester Guild Merchant 1159'. It was used to denote periods of free trade in the city and, together with its inscription, suggests a definite link between the Guild Merchant and trade in general. See R. Stewart-Brown, 'Notes on the Chester Hand or Glove', J.C.A.S., 20 (1914), pp. 126-8.

3. M.J. Groombridge, Guide to the Charters, Plate and Insignia of the City of Chester (Chester, no date), p. 15.

4. J.H.E. Bennett, 'The Rolls of the Freemen of the City of Chester, pt I, 1392-1700', Record Society of Lancashire and Cheshire, (hereafter R.S.L.C.), 51 (1906).

5. G.H. Parry, 'The History of the Chester Guilds', pt 3, The Deva Pentice, no. 3 (May, 1973), p. 27.

6. Simpson, J.C.A.S., 18 (1911), p. 98. F.A. Hibbert, 'The Gild History of Chester', J.C.A.S., 5, pt 1 (1893), p. 5.

7. An explanation of these trades can be found in C. Waters, A Dictionary of Old Trades, Titles and Occupations Newbury, 1999).

8. Boulton, Mystery Plays, pp. 4-6.

9. Chester Freeman and Guilds (no pagination or dates), Chester History and Heritage, study pack.

10. Simpson, J.C.A.S, 18 (1911), pp. 98-203 (188-190). 
11. Merchant Drapers and Hosiers Company: Account Book Extracts. Folio 33. Chester History and Heritage, ref. 942.714.338.632MER. The term 'quartring' (or quarterage) referred to a quarterly membership fee, as later described. Obviously, the steward would not have been expected to pay the fee for his dead colleague unless he had failed to collect it in a timely manner when the man was alive.

12. Skinners and Feltmakers Company: Order Book, 1615-1795, pp. 22-26 for all oaths. For a comparison, see Merchant Drapers and Hosiers Account Book Extracts, Folio 3. Chester History and Heritage, ref. 942.714.338.632MER.

13. Joiners, Turners and Carvers Company: Company Book, 1576-1756, p. 167.

14. Barber Surgeons Company: Company Book, 1606-1698, p. 106. For a more detailed description of the impact of women upon the Chester companies, see M.J. Groombridge, 'The City Gilds of Chester' J.C.A.S., 39 (1952), p. 6. For more information on the role of the Barber Surgeons Company, see Simpson, J.C.A.S., 18 (1911), pp.100-101.

15. The Ancient and Worshipful Company of Butchers: Company Book Extracts, (no pagination), 17 Nov. 1656. Chester History and Heritage, Ref. 942.714.338.632ANC.

16. The Phoenix Tower was originally called The Newton Tower. Its name was changed by the Painters, Glaziers, Embroiderers and Stationers Company whose company badge contained a Phoenix and was attached to the tower in 1613. Charles I is said to have watched the battle of Rowton Moor from the tower, in 1645, and it has borne his name ever since. See G. Emery, Chester Inside Out (Chester, 1998), p. 63.

17. Barber Surgeons Company: Company Book, 1692-1791, p. 21.

18. Barber Surgeons Company: Company Book, 1606-1698, p. 70.

19. F. Simpson, 'The City Gilds or Companies of Chester: The Smiths, Cutlers and Plumbers Company', J.C.A.S., 20 (1914), p. 57.

20. F. Simpson, 'The City Gilds of Chester: The Bricklayers Company', J.C.A.S., 22 (1918), p. 61.

21. Groombridge, J.C.A.S., 39 (1952), pp. 4-5.

22. Simpson, J.C.A.S., 20 (1914), p. 34.

23. Skinners and Feltmakers Company: Order Book, 1615-1795, p. 17.

24. Bricklayers Company: Company Book, 1681-1895, rule 10 (no pagination). 
25. For example, The Worshipful Company of Goldsmiths and Watchmakers 1663-1803: Account Book, p. 86, The Barber Surgeons Company: Company Book, 1606-1698, p. 57. See also The Ancient and Worshipful Company of Butchers: Company Book Extracts, (no pagination), Chester History and Heritage, ref. 942.714.338.632ANC, 3 Jul. 1620 for company refusal to pay this fee which eventually led to its discontinuation in the eighteenth century.

26. Simpson, J.C.A.S., 20 (1914), p. 34.

27. Bricklayers Company: Company Book, Rule 7, (no pagination).

28. Smiths, Cutlers and Plumbers Company: Account Book, 1637-1902, p. 14.

29. Smiths, Cutlers and Plumbers Company: Account Book, 1637-1902, p. 32.

30. Smiths, Cutlers and Plumbers Company: Account Book, 1637-1902, p. 27, 48.

31. For Example, Barber Surgeons Company: Company Book, 1606-1698, p. 88, Merchant Drapers and Hosiers Company: Account Book Extracts, Chester History and Heritage, ref. 942.714.338.632MER. Folio 33 for quote.

32. F. Simpson, 'The City Gilds or Companies of Chester: The Skinners and Feltmakers Company', J.C.A.S., 21 (1915), p. 94.

33. Merchant Drapers and Hosiers Company: Account Book Extracts, Chester History and Heritage, ref. 942.714.338.632MER. Folio 14, 33.

34. Simpson, J.C.A.S., 22 (1918), p. 64. The Ancient and Worshipful Company of Butchers: Company Book Extracts, (no pagination), 17 Nov. 1656, Chester History and Heritage, ref. 942.714.338.632ANC.

35. Bricklayers Company: Company Book, 1681-1895, rule 5 (no pagination). Merchant Drapers and Hosiers Company: Account Book Extracts, Chester History and Heritage, ref. 942.714.338.632MER. Folio 1 (1637). Barber Surgeons Company: Company Book, 1606-1698, p. 13.

36. Smiths, Cutlers and Plumbers Company: Minute Book, 1670-1708, p. 3. Barber Surgeons Company: Company Book, 1606-1698, pp. 15-16.

37. J.S. Morrill, Cheshire 1630-1660: County Government and Society During the English Revolution (OUP, 1974), p. 181.

38 Bennett, R.S.L.C., 51 (1906), pp. 125-129. A figure which contrasts sharply with the 122 men granted freedom in the two years following the end of the conflict.

39 G.H. Parry, 'The History of the Chester Guilds', pt 3, The Deva Pentice, no. 7 (March, 1973), pp. 13-15 (15).

40 Smiths, Cutlers and Plumbers Company: Account Book, 1637-1902, p. 34, 40. 
41 R. Stewart-Brown, 'The Stationerers, Booksellers and Printers of Chester to about 1800', R.S.L.C., 83 (1931), p. 113.

42 Simpson, J.C.A.S., 18 (1911), p. 139.

43 R.H. Morris, The Siege of Chester 1643-1646, (Chester, 1924), Appendix 1, p. 223. Glovers Company: Company Book, 1629-1960 (no pagination).

44 Glovers Company: Company Book, 1629-1960 (no pagination).

45 There only exist membership numbers for the Innholders, Cooks and Victuallers Company for 1642, 1643, 1644, 1656 and 1660. These comprise a number of loose documents held at the Chester and Cheshire Record Office (Ref. ZG13/27).

46 J. Barratt, The Great Siege of Chester, (Stroud, 2003), p. 71.

47 Merchant Drapers and Hosiers Company: Account Book Extracts, Chester History and Heritage, ref. 942.714.338.632MER. Folio 33, 24 Oct. 1644, 11 Mar. 1645.

48 Barber Surgeons Company: Company Book, 1606-1698, p. 112.

49 Mercers Company: Company Book (no pagination). Until recently this book belonged in a private collection. It currently resides unreferenced in the Chester and Cheshire Record Office. My thanks to Katy Goodrum for bringing it to my attention.

50 Skinners and Feltmakers Company: Order Book, 1615-1795, p. 17.

51 M.J. Groombridge, ed., 'Calendar of Chester City Council Minutes 1603-1642', R.S.L.C., 106 (1956), p. 14. Dec. 1646 for this edict.

52 'Apprenticeship Indentures, 1600-1684' reproduced in The Cheshire Sheaf, 3rd Series, 8, (1910), pp. 4-59.

53 C.H. Firth and R.S. Rait, eds., Acts and Ordinances of the Interregnum 1642-1606, vol. I. Mar.1642 to Jan. 1649 (HMSO, London, 1911), pp. 1054-55.

54 Smiths, Cutlers and Plumbers Company: Account Book, 1637-1902, p. 4.

55 Groombridge, R.S.L.C., 106, (1956), p. 33.

56 Firth and Rait, eds., Acts and Ordinances, pp. 1006-7, 1654.

57 A.M. Johnson, 'Politics in Chester during the Civil Wars and the Interregnum' in P. Clark, \& P. Slack, eds., Crisis and Order in English Towns 1500-1700 (London, 1972), pp. 204-236 (214-215). 
58 Barber Surgeons Company: Company Book, 1606-1698, p. 54. This figure of one-third is calculated from Morris, Siege of Chester, p. 210, where it is claimed plague killed 2099 Cestrians. G.C.F. Forster, 'Early Modern Chester 1550-1762' in The Victoria History of the Counties of England: A History of the County of Chester, vol. 5 pt. I. (London, 2003), p. 91, claims the population of Chester was 6503 in 1629 and 6742 in 1660. No figure is provided for 1646 but as the effects of the civil war would have seen it decrease, it is reasonable to suggest that 2099 people represented approximately onethird of the remaining population.

59 Joiners, Turners and Carvers Company: Company Book, 1576-1756, p. 170, 173. Barber Surgeons Company: Company Book, 1606-1698, pp. 54-55. Merchant Drapers and Hosiers Account Book Extracts, Chester History and Heritage, ref. 942.714.338.632MER. Folio 33, 25 Sept. 1646, 25 Sept. 1647.

60 Assembly Orders: Saddlers and Curriers Company, p. 15.

61 Assembly Orders: Merchant Taylors Company, p. 17, Innholders Company, p. 16, Joiners, Turners and Carvers, p. 31.

62 Assembly Orders, p. 28.

63 Forster, 'Early Modern Chester', p. 122 for Skinners \& Feltmakers. Mercers Company: Company Book (no pagination) shows membership of 47 in 1642, rising to 57 by 1649 .

64 Simpson, J.C.A.S., 20 (1914), p. 57.

65 As reproduced in D.M. Palliser, ed., Chester 1066-1971: Contemporary descriptions by residents and visitors, (Chester, 1972), p. 15.

66 For more detail of the city during the siege, see Barratt, The Great Siege, esp. Chs. 4 and 5.

67 For information on these fairs, and one other - the 'Hoof and Horn Fair' - which commenced in 1685 and lasted just one day - see Stewart-Brown, J.C.A.S., 20 (1914).

68 Merchant Drapers and Hosiers Company: Account Book Extracts. Chester History and Heritage, ref. 942.714.338.632MER. Folio 33. Thomas Knee was probably a 'Leve Looker' - a government official responsible for, among other things, identifying and indicting foreigners who continued trading after the fairs had ended. Also, Smiths, Cutlers and Plumbers Company: Account Book, 1637-1902, p. 16.

69 Barber Surgeons Company: Company Book, 1606-1698, p. 116.

70 Groombridge, R.S.L.C., 106 (1956), p. 65.

71 For Example, Smiths, Cutlers and Plumbers Company: Minute Book, 1670-1708, (no pagination).

72 Groombridge, R.S.L.C., 106 (1956), p. vii. 
73 Groombridge, R.S.L.C., 106 (1956), p. 140 (fn).

74 Simpson, J.C.A.S., 18 (1911), pp. 125-128. Groombridge, R.S.L.C., 106 (1956), p. vii, 45 (fn). Forster, 'Early Modern Chester', pp. 90-146 (106).

75 Barber Surgeons Company: Company Book, 1606-1698, p. 58, 114

76 Groombridge, R.S.L.C., 106 (1956), p. 140 (fn).

77 For a detailed description of the Midsummer Show, its history and format, see F.R.G. Duckworth, Chester (London, 1910), Ch. 4. pp. 146-154.

78 Smiths, Cutlers and Plumbers Company: Account Book, 1637-1902, pp. 24-26. Duckworth, Chester, p. 149. As Randle Holme recorded this expense, it is likely the company involved was the Painters, Glaziers, Stationers and Embroiderers to which he belonged. Also, Barber Surgeons Company: Company Book, 1606-1698, p. 14.

79 For more information on the outlawing of traditional forms of entertainment - including the Mystery Plays, football and a sprint race - see D. Bethell, Portrait of Chester (London, 1980), pp. 84-85.

80 The Ancient and Worshipful Company of Butchers: Company Book Extracts, (no pagination), 1661-2 accounts. Chester History and Heritage, Ref. 942.714.338.632ANC. Simpson, J.C.A.S., 18 (1911), p. 163 and J.C.A.S., 20 (1914), p. 73.

81 This badge will soon be available to view at the Chester and Cheshire Record Office.

82 By 1700, Chester was the main port in the area for customs administration. Trade taxes were numerous, as might be expected in a century where succeeding King's were in almost constant dispute with Parliament over subsidies. One such tax was the tax on French wine. The freemen were released from this particular tax, in 1634, by royal consent (see Harliean Manuscript MS2004.22, available on microfilm at Chester History and Heritage). The benefit to Innkeepers has already been demonstrated by the various fees paid by the companies, notably the Smiths, Cutlers and Plumbers, during their election days. Other common social occasions, where the comfort of an inn was usually sought, were the numerous festivities associated with royalty. One example is the $14 \mathrm{~s} 4 \mathrm{~d}$ 'spent upon the proclamation of the Kinge', in 1660. See Joiners, Turners and Carvers Company Book, 1576-1756, p. 201.

83 Smiths, Cutlers and Plumbers Company: Account Book, 1637-1902, p. 28, 36, 70. Joiners, Turners and Carvers Company Book, 1576-1756, p. 206.

84 Barber Surgeons Company: Company Book, 1606-1698, p. 69 and The Ancient and Worshipful Company of Butchers: Company Book Extracts, (no page nos.), 25 May 1660. Chester History and Heritage, Ref. 942.714.338.632ANC.

85 Rule 17 of the Barber Surgeons Company: Company Book, 1692-1791, p. 13. 
86 Skinners and Feltmakers Company: Order Book, 1615-1795, pp. 33-4 and Barber Surgeons Company: Company Book, 1692-1791, p. 13. This last rule is interesting as the lines referring to dependents and servants is crossed out. A note in the corner of the book suggests this occurred in 1704 when the company reverted to attendance at the funeral of their brethren only.

87 Simpson, J.C.A.S., 20 (1914), p. 25.

88 Groombridge, R.S.L.C., 106 (1956), p. 25.

89 Merchant Drapers and Hosiers Company: Account Book Extracts. Folio 33. 17 Oct. 1655. Chester History and Heritage, ref. 942.714.338.632MER.

90 Groombridge, R.S.L.C., 106 (1956), p. xxviii. For democracy, or lack of it, see Simpson, J.C.A.S., 20 (1914), pp. 15-16.

91 Bricklayers Company: Company Book, 1681-1895, rule 16 (no pagination).

92 Simpson, J.C.A.S., 20 (1914), p. 44.

93 The Will of Owen Jones, 1658. Part of the Mercers Company material (unreferenced). This will is one of the many copies bought by the various companies for their own records shortly after Owen Jones' death. Also, Simpson, J.C.A.S., 18 (1911), p. 143.

94 Simpson, J.C.A.S., 18 (1911), p. 143-148 (145).

95 Forster, 'Early Modern Chester', p. 140.

96 Groombridge, J.C.A.S., 39 (1952), p. 6.

97 A.M. Kennett, Brief Histories of the Chester City Companies or Guilds (Chester Record Office, 1985).

98 The two extinct Companies are the Drawers of the Dee and the Fishmongers.

99 For more information on the modern-day guilds and companies of Chester, see Chester Freeman and Guilds (no date or pagination), Chester History and Heritage, study pack. 


\section{BIBLIOGRAPHY}

Primary Sources C.C.R.O. = Chester and Cheshire Record Office.

C.H.H. = Chester History and Heritage Centre.

\section{Company Books}

Barber Surgeons Company: Company Book, 1606-1698 C.C.R.O. (ref. ZG20/1)

Barber Surgeons Company: Company Book, 1692-1791 C.C.R.O. (ref. ZG2/2)

Bricklayers Company: Company Book, 1681-1895 C.C.R.O. (ref. ZG4/1)

Drawers of the Dee: Company Book, 1571-1712 C.C.R.O. (ref. ZG10/1)

The Ancient and Worshipful Company of Butchers: Company Book Extracts, C.H.H. (ref. 942.714.338.632ANC)

Glovers Company: Company Book, 1629-1960 C.C.R.O. (ref. ZG11/1)

The Worshipful Company of Goldsmiths and Watchmakers: Account Book, 1663-1803 C.C.R.O. (ref. ZG/12)

Innholders, Cooks and Victuallers Company: Membership Lists, 1599-1669

C.C.R.O. (ref. ZG13/27)

Joiners, Turners and Carvers Company: Company Book, 1576-1756

C.C.R.O. (ZG14/1)

Mercers Company: Company Book C.C.R.O. (unreferenced)

Merchant Drapers and Hosiers Company: Account Book Extracts.

C.H.H. (ref. 942.714.338.632MER)

Skinners and Feltmakers Company: Order Book, 1615-1795

C.C.R.O. (ref. ZG19/1)

Smiths, Cutlers and Plumbers Company: Account Book, 1637-1902

C.C.R.O. (ref. ZG20/1)

Smiths, Cutlers and Plumbers Company: Minute Book, 1670-1708

C.C.R.O. (ref. ZG20/6)

Smiths, Cutlers and Plumbers Company: Book of Fines, 1653-1678

C.C.R.O. (ref. ZG20/2) 


\section{Primary Sources (other)}

Assembly Orders

C.C.R.O. (ref. A.O.1)

Bennett, J.H.E., The Rolls of the Freemen of the City of Chester part I, 1392-1700 Record Society of Lancashire and Cheshire Vol. 51 (1906)

Cheshire Apprenticeship Indentures, 1557-1646 The Cheshire Sheaf, Vol. 8 (1910)

Firth, C.H. \& Rait, R.S. (eds.), Acts and Ordinances of the Interregnum 1642-1606 Vol. I. March 1642 to Jan, 1649 (HMSO, London, 1911)

Firth, C.H. \& Rait, R.S. (eds.), Acts and Ordinances of the Interregnum 1642-1606 Vol. II. Feb, 1649, to March, 1660 (HMSO, London, 1911)

Groombridge, M.J. (ed.), Calendar of Chester City Council Minutes, 1603-1642 Transactions of the Record Society of Lancashire and Cheshire Vol. 106 (1956)

Palliser, D.M. (ed.), Chester 1066-1971: Contemporary descriptions by residents and visitors, (Chester, 1972)

Owen Jones's Will, 1658

C.C.R.O (unreferenced) 


\section{Secondary Sources: Books}

Barratt, J., The Great Siege of Chester $\quad$ (Stroud, 2003)

Bethell, D., Portrait of Chester $\quad$ (London, 1980)

Boulton, H.E., The Chester Mystery Plays $\quad$ (Chester, 1980)

Clark, P. and Slack, P. (eds.), Crisis and Order in English Towns 1500-1700

(London, 1972)

Crossley, F.H., Cheshire $\quad$ (London, 1949)

Dore, R.N., Cheshire $\quad$ (London, 1977)

Dore, R.N., The Civil Wars in Cheshire $\quad$ (Chester, 1966)

Duckworth, F.R.G., $\underline{\text { Chester } \quad \text { (London, 1910) }}$

Emery, G., Chester Inside Out: A Souvenir Guide $\quad$ (Chester, 1998)

Groombridge, M.J., Guide to the Charters, Plate and Insignia of the City of Chester (Chester, c. 1950)

Harrison, S., Kennett, A.M.,

Shepherd, E. \& Willshaw, E.M., Loyal Chester $\quad$ (C.C.R.O., 1984)

Hughes, T., The Stranger's Handbook to Chester New Edition (Manchester, 1972)

Kennett, A.M., Brief Histories of the Chester City Companies or Guilds (C.C.R.O., 1985).

Morrill, J., Cheshire 1630-1660: County Government and Society During the English Revolution (OUP, 1974)

Morrill, J., Revolt in the Provinces: The People of England and the Tragedies of War 1630$\underline{1648}$ 2nd edition (London, 1999)

Morris, R.H., The Siege of Chester 1643-1646 $\quad$ (Chester, 1924)

Morriss, R.K., The Buildings of Chester $\quad$ (Stroud, 1993)

Simpson, F., The Chester City Gilds: The Skinners and Feltmakers Company

(Chester, 1915)

Sylvester, D., A History of Cheshire $\quad$ (Oxon, 1971)

University of London Institute of Historical Research The Victoria History of the Counties of England: A History of the County of Chester Vol. 5 (London, 2003) 
Waters, C., A Dictionary of Old Trades, Titles and Occupations, $\quad$ (Newbury, 1999)

Ward, H., Freemen in England $\quad$ (London, 1975)

\section{Secondary Sources: Journals}

Groombridge, M.J., The City Gilds of Chester Journal of the Chester Archaeological Society Vol. 39 (1952)

Hibbert, F.A., The Gild History of Chester Journal of the Chester Archaeological Society New Series, Vol. 5 (1893)

Hughes, T., On Chester Literature, its Authors and Publishers, during the Sixteenth and Seventeenth Centuries Journal of the Chester Archaeological Society 1st Series, Vol. 2 (1864)

Morrill, J.S. \& Dore, R.N., The Allegiance of the Cheshire Gentry in the Great Civil War Transactions of the Lancashire and Cheshire Antiquarian Society Vol. 77 (1974)

Parry, G.H., The History of the Chester Guilds, Part 1 The Deva Pentice No. 1 (January, 1972)

Parry, G.H., The History of the Chester Guilds, Part 2 The Deva Pentice No. 2 (September, 1972)

Parry, G.H., The History of the Chester Guilds, Part 3 The Deva Pentice No. 3 (March, 1973)

Parry, G.H., The History of the Chester Guilds, Part 4 The Deva Pentice No. 7 (September, 1974)

Ridgway, M.H., Chester Goldsmiths: From early times to 1726 Journal of the Chester Archaeological Society Vol. 53 (1966)

Simpson, F., The City Gilds or Companies of Chester with special reference to that of the Barber Surgeons Journal of the Chester Archaeological Society New Series, Vol. 18 (1911)

Simpson, F., The City Gilds or Companies of Chester: The Smiths, Cutlers and Plumbers Company Journal of the Chester Archaeological Society New Series, Vol. 20 (1914)

Simpson, F., The City Gilds or Companies of Chester: The Skinners and Feltmakers Company Journal of the Chester Archaeological Society New Series, Vol. 21 (1915)

Simpson, F., The City Gilds or Companies of Chester: The Bricklayers Company Journal of the Chester Archaeological Society New Series, Vol. 22 (1918)

Stewart-Brown, R., The Stationers, Booksellers and Printers of Chester to About 1800 Journal of the Chester Archaeological Society New Series, Vol. 20 (1914) 
Stewart-Brown, R., Notes on the Chester Hand or Glove Transactions of the Historic Society of Lancashire \& Cheshire Vol. 83 (1932)

Woodward, D.M., The Chester Leather Industry, 1558-1625 Transactions of the Historic Society of Lancashire \& Cheshire Vol. 119 (1968)

\section{Secondary Sources: Miscellaneous}

Chester Freeman and Guilds

C.H.H. study pack (no ref.) 


\section{APPENDIX 1}

Selected Company Membership Fluctuation during the Civil War

Period

Fig. 1: Joiners, Turners and Carvers Company

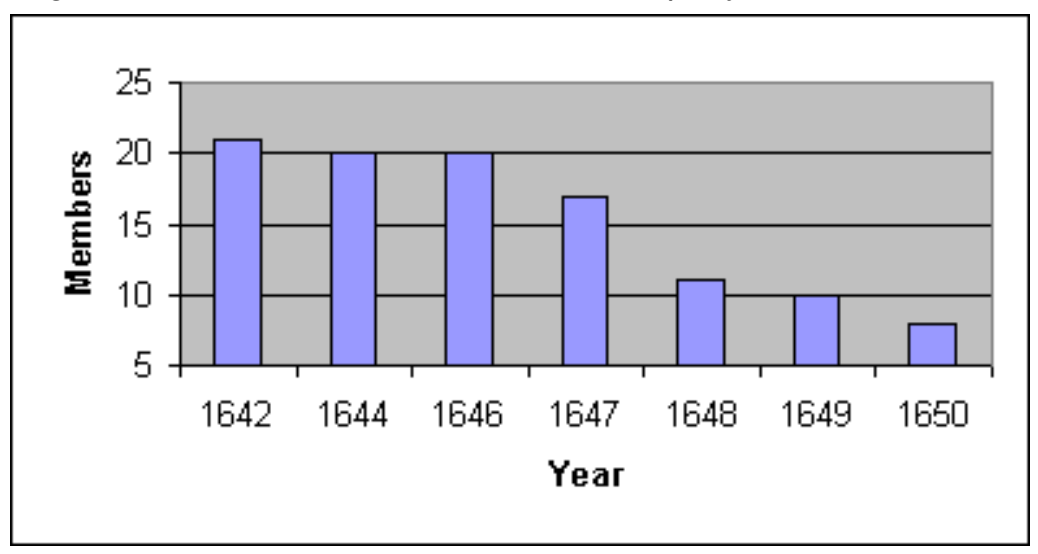

Fig. 2: Mercers Company

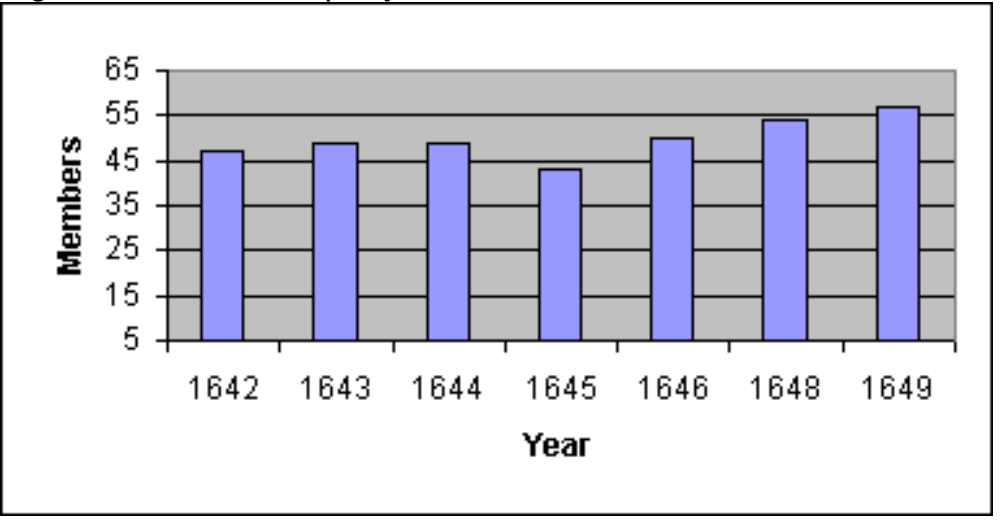

Fig. 3: Barber Surgeons Company

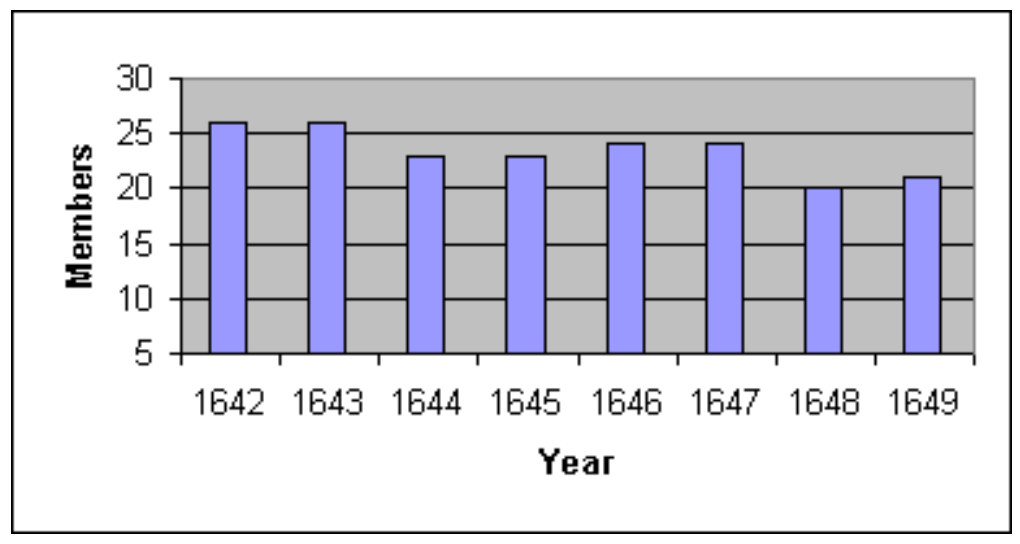

Fig. 4: Merchant Drapers and Hosiers Company

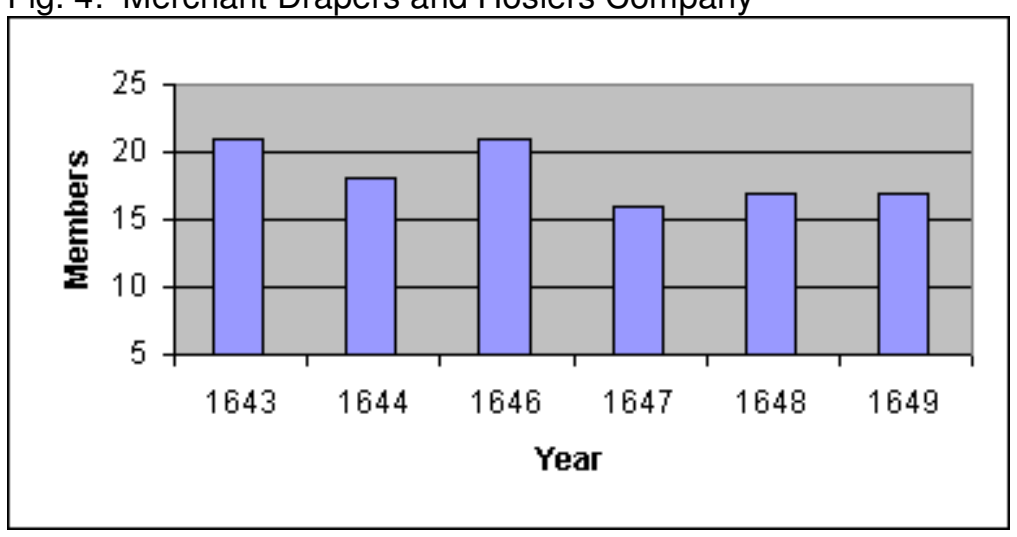


